Jurnal Kirana 2020 Vol. 1(1): 12-18

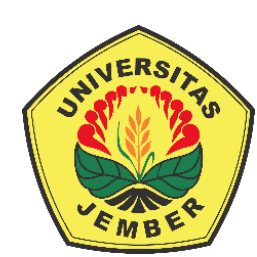

Jurnal Komunikasi dan Penyuluhan Pertanian Journal of Communication and Agricultural Extension email: jurnalkirana@unej.ac.id https://jurnal.unej.ac.id/index.php/jkrn

\title{
Dampak Penggunaan Keramba Jaring Apung pada Pembudidaya Ikan Kerapu Berdasarkan Perspektif Sosial Ekonomi)
}

\section{Impact of Using Floating Net Cages on Grouper Farmers Based on Socio-Economic Perspective}

\section{Lenny Widjayanthi ${ }^{\bowtie}$ dan Yeni Anggun Widayanti ${ }^{2}$}

${ }^{1}$ Program Studi Penyuluhan Pertanian Fakultas Pertanian Universitas Jember

2 Program Studi Agribisnis Fakultas Pertanian Universitas Jember

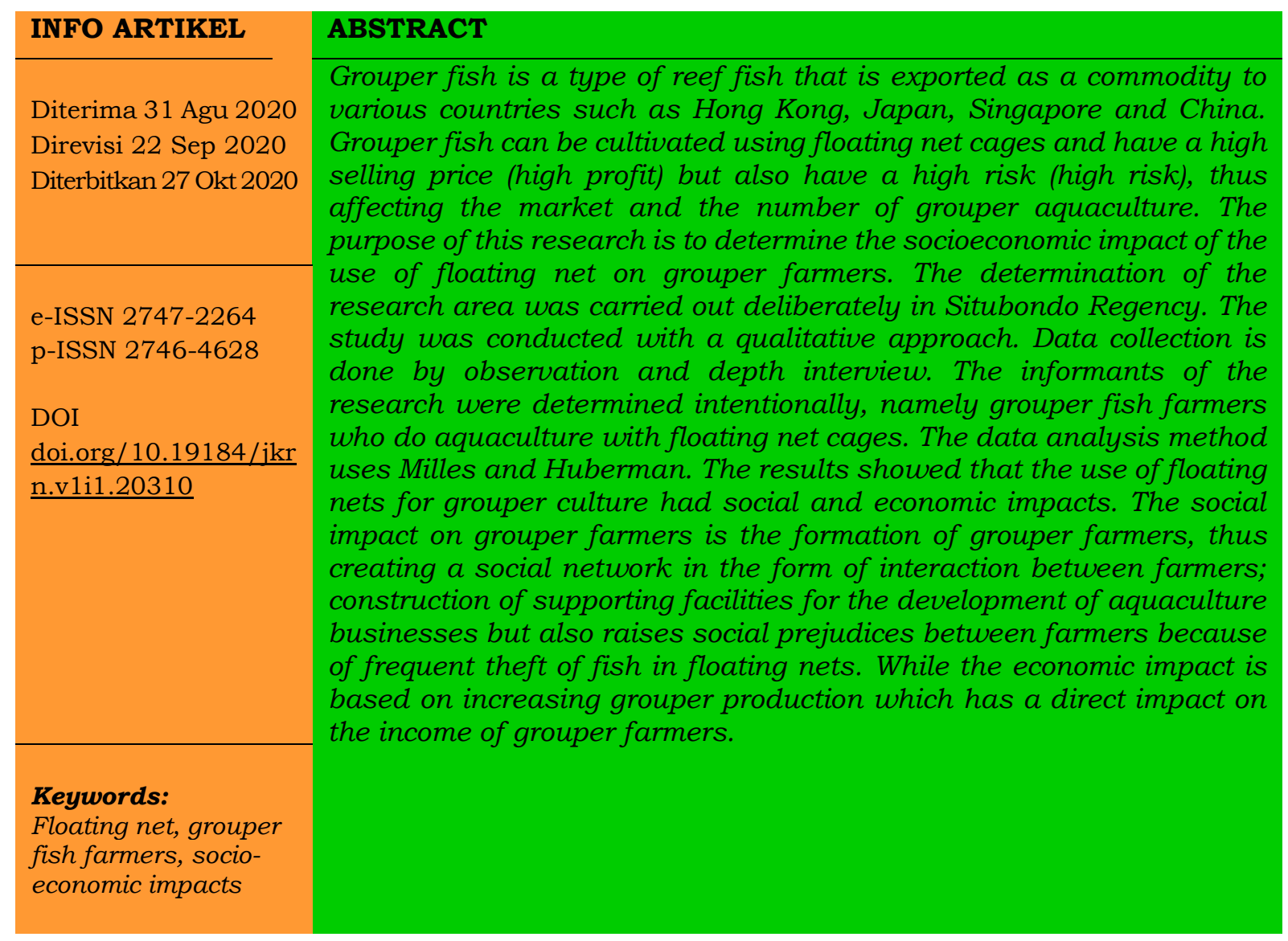

$凶$ Penulis Koresponden :

E-mail : lenny.faperta@unej.ac.id 


\begin{tabular}{|c|c|}
\hline & ABSTRAK \\
\hline & $\begin{array}{l}\text { Ikan Kerapu adalah salah satu jenis ikan karang yang telah menjadi } \\
\text { komoditas ekspor penting ke berbagai negara seperti misalnya } \\
\text { Hongkong, Jepang, Singapura dan Cina. Ikan kerapu dapat } \\
\text { dibudidaya dengan menggunakan kerambajaring apung dan memiliki } \\
\text { harga jual tinggi (high profit) tetapi juga memiliki resiko yang tinggi } \\
\text { (high risk), sehingga berdampak pada pasar dan perkembangan } \\
\text { budidaya ikan kerapu. Tujuan penelituan untuk menegetahui dampak } \\
\text { social ekonomipenggunaan jarring apung terhadap pembudidaya ikan } \\
\text { kerapu. Penentuan daerah penelitian dilakukan secara sengaja di } \\
\text { desa Klataka, Kabupaten Situbondo. Penelitian dilakukan dengan } \\
\text { pendekatan kualitatif. Pengumpulan data dilakukan dengan, } \\
\text { observasi dan depth interview. Informan penelitian ditentukan secara } \\
\text { sengaja yaitu pembudidaya ikan kerapu yang menggunakan keramba } \\
\text { jarring apung. Metode analisis data menggunakan Milles dan } \\
\text { Huberman. Hasil penelitian menunjukkan bahwa penggunaan jarring } \\
\text { apung untuk budidaya ikan kerapu memberikan dampak social dan } \\
\text { ekonomi. Dampak social pada pembudidaya ikan kerapu adalah } \\
\text { terbentuknya kelompok pembudidaya ikan kerapu sehingga } \\
\text { menciptakan jaringan social berupa interaksi antar pembudidaya, } \\
\text { dibangunnya fasilitas penunjang untuk perkembangan usaha } \\
\text { budidaya tetapi juga memunculkan prasangka social antar } \\
\text { pembudaya karena seringnya terjadi pencurian ikan di tambak. } \\
\text { Sedangkan dampak ekonomi didasarkan pada peningkatan produksi }\end{array}$ \\
\hline $\begin{array}{l}\text { Kata kunci: } \\
\text { Keramba jarring } \\
\text { apung, pembudidaya }\end{array}$ & $\begin{array}{l}\text { ikan kerapu yang berdampak langsung terhadap pendapatan } \\
\text { pembudidaya ikan kerapu. }\end{array}$ \\
\hline $\begin{array}{l}\text { ikan kerapu, dampak } \\
\text { Sosial ekonomi }\end{array}$ & (C) 2020, PS Penyuluhan Pertanian UNEJ \\
\hline
\end{tabular}

\section{PENDAHULUAN}

Negara Indonesia memiliki potensi budidaya perikanan tambak dan laut yang sangat besar. Beberapa jenis spesies yang berpotensi menjadi komoditas budidaya adalah udang, ikan, teripang, kerang dan rumput laut. Beberapa jenis ikan laut seperti ikan kerapu macan, ikan kerapu bebek atau tikus, ikan kerapu cantang, ikan kerapu lumpur merupakan ikan laut yang mempunyai prospek pengembangan yang cukup cerah baik di pasar nasional maupun internasional (Langkosono, 2007; Triana, 2010). Ikan kerapu diketahui merupakan salah satu komoditas yang penting karena bersifat Export Oriented sehingga nilai jualnya makin tinggi ketika nilai tukar dollar makin menguat (Rahmaningsih \& Ari, 2013). Ikan kerapu merupakan salah satu komoditas perikanan unggulan ekspor Indonesia yang mempunyai nilai ekonomi tinggi (Loekman, Satyantini, \& Mukti, 2018).

Di Indonesia permintaan konsumen dalam negeri terhadap ikan kerapu hidup dan segar cukup besar terutama oleh restoran-restoran makanan laut (sea food) dan hotel-hotel berbintang. Sedangkan permintaan ekspor juga cenderung meningkat setiap tahunnya, terutama ekspor ikan kerapu hidup dan segar ke Singapura dan Hongkong. Selain itu, ekspor ikan kerapu dalam bentuk fillet memiliki pangsa pasar yang juga cukup tinggi (Gunarto, 2003). Wilayah penyebaran ikan kerapu meliputi daerah tropic dan sub tropic (Paruntu, 2019). Budidaya kerapu di Indonesia tersebar dari Sumatera Utara, Kepulauan Riau, Lampung, Jawa Timur dan Bali (Renanti, 2015). 
Komoditas ikan kerapu merupakan salah satu komoditas utama ekspor ikan Indonesia yang diperdagangkan dalam bentuk hidup dan mati (segar dan beku). Data BPS menyebutkan ikan kerapu hidup masuk dalam 20 jenis komoditas utama ekspor ikan Indonesia tahun 2016. Total nilai ekspor ikan kerapu hidup tahun 2016 mencapai 32,18 Juta US \$ (Suhana, 2017). Kegiatan perikanan ikan kerapu semakin digalakkan sejalan dengan bertambahnya permintaan. Ikan kerapu diperdagangkan dalam bentuk hidup untuk memenuhi kebutuhan pasar Hongkong, China, Taiwan, Singapura, Malaysia dan negara lainnya (Ismi, 2013).

Budidaya ikan kerapu meningkatkan pendapatan masyarakat desa, meningkatkan pengetahuan di bidang budidaya perikanan dan membuka peluang diversifikasi usaha perikanan, sehingga hal tersebut berimplikasi terhadap kondisi sosial ekonomi masyarakat nelayan (Bian, 2010). Dampak positif budidaya ikan kerapu yaitu terjadinya peningkatan usaha dan terbukanya kesempatan kerja atau lapangan pekerjaan baru bagi masyarakat sekitar, dimana hal ini akan berpengaruh pada pendapatan (Adhyaksa, 2008).

Keramba jaring apung merupakan salah satu teknik budidaya yang memerlukan biaya tidak sedikit, sehingga masyarakat yang ingin melakukan budidaya butuh berpikir panjang untuk memulai usaha tersebut dan masalah seperti fluktuasi harga ikan dikarenakan tingkat ketahanan ikan (survival rate) yang mulai menurun, serta berkurangnya intensitas pengiriman ikan khususnya untuk pengiriman ekspor menjadi salah satu kendala yang cukup berpengaruh bagi masyarakat, sehingga hal ini menyebabkan jumlah pembudidaya ikan kerapu yang tidak tetap atau fluktuatif. Oleh karena itu, peneliti inigin mengetahui bagaimana dampak social ekonomi penggunaan keramba jarring apung pada pembudidaya ikan kerapu di Desa Klatakan.

\section{METODE PENELITIAN}

Penentuan daerah penelitian dilakukan secara sengaja yaitu Desa Klatakan Kabupaten Situbondo. Metode penelitian menggunakanparadigma penelitian kualitatif. Metode penentuan informan dilakukan secara purposive yaitu Pembudidaya Ikan Keramba Jaring Apung. Pengumpulan data dilakukan dengan wawancara, observasi dan studi dokumentasi. Analisis data menggunakan model Miles dan Huberman. Uji keabsahan data dilakukan dengan triangulasi sumber (Moleong, 2010).

\section{HASIL DAN PEMBAHASAN}

Dampak Sosial Ekonomi Pembudidaya Ikan Kerapu Malam Menggunakan Keramba Jaring Apung. Setiap kehidupan masyarakat, senantiasa mengalami perubahan. Perubahan-perubahan pada kehidupan masyarakat merupakan fenomena sosial yang wajar, oleh karena setiap manusia mempunyai kepentingan yang tak terbatas. Kegiatan budidaya ikan kerapu cukup berpengaruh terhadap kondisi sosial ekonomi pelaku usaha atau pembudidaya.

\section{Dampak Sosial}

Dampak sosial adalah sebuah bentuk akibat atau pengaruh yang terjadi karena adanya sesuatu hal. Pengaruh yang dimaksud adalah akibat yang terjadi pada masyarakat, baik karena suatu kejadian itu mempengaruhi masyarakat atau hal lainnya didalam masyarakat. Dampak sosial penggunaan keramba jaring apung 
antara lain adanya interaksi sosial, prasangka sosial, perkembangan aksesibilitas dan terpenuhinya kebutuhan keluarga. Interaksi sosial diartikan sebagai hubungan-hubungan sosial yang dinamis berupa hubungan antara individu yang satu dengan individu lain, antara kelompok yang satu dengan kelompok lainnya, maupun antara kelompok dengan individu. Hal tersebut dilakukan untuk menunjang produksi. Interaksi yang terjadi adalah interaksi antar individu yaitu komunikasi antara satu dengan lainnya, pembudidaya dengan pemodal besar dan pembudaya dengan instansi.

Dampak sosial yang terjadi setelah adanya usaha budidaya ikan kerapu keramba jaring apung:

a. Terbentuknya jejaring atau perkumpulan pembudidaya ikan kerapu menggunakan keramba jaring apung

Interaksi antar individu khususnya pembudidaya ikan kerapu menghasilkan sebuah perkumpulan yang juga ikut digagas oleh pemerintah di Kabupaten Situbondo. Terbentuknya Perkumpulan Pembudidaya Ikan Keramba Jaring Apung (PPIK) pada tahun 2014 dijadikan sebagai tempat sharing pembudidaya tentang produksi dan pemasaran ikan kerapu. Terbentuknya suatu interaksi sosial dalam sebuah perkumpulan atau kelompok masyarakat tertentu dilandaskan oleh norma yang dibentuk dan disetujui oleh kelompok masyarakat dan pola interaksi yang terjadi berbeda dengan pola interaksi di suatu perkumpulan atau kelompok masyarakat lainnya. Selaras dengan penelitian yang dilakukan oleh Arifin (2015), bahwa interaksi sosial terjadi dalam berbagai bentuk antara lain kerjasama, persaingan, pertikaian atau pertentangan dan akomodasi. Salah satu bentuk kerjasama yang dilakukan pembudidaya adalah dengan membentuk suatu perkumpulan untuk mempermudah pembudidaya dalam akses informasi pasar, selain itu juga sebagai penghubung antara instansi atau lembaga di Kabupaten Situbondo dengan pembudidaya. Hubungan sosial antara pembudidaya satu dan yang lain baik satu maupun beda desa cukup terintegrasi misalnya koordinasi untuk penyebaran bantuan dan penyuluhan. Selain itu antar pembudidaya saling bertukar ilmu dan informasi tentang permintaan pasar ikan kerapu.

b. Munculnya prasangka sosial antar pembudidaya

Pembudidaya ikan kerapu menyatakan ada persaingan dalam melakukan usaha budidaya. Hal tersebut berupa kecurangan yang terjadi diantara mereka seperti jumlah ikan di keramba yang tiba-tiba menyusut atau menghilang. Pembudidaya menganggap ikan yang hilang karena dicuri. Mereka menyatakan hanya bisa merelakan jika hal itu terjadi karena hal tersebut juga termasuk dalam kelalaian. Antisipasi yang dilakukan adalah dengan melakukan penjagaan pada keramba di malam hari, tapi hal itu tidak selalu dilakukan. Hal lain yang dilakukan oleh pembudidaya adalah memastikan jumlah ikan dengan rutin melakukan pengecekan jumlah ikan saat proses grading, terdapat pembukuan jumlah ikan yang masih hidup, terkena penyakit, ikan mati dan hilang. Menurut (Ahmadi, 2004) prasangka sosial adalah sikap negatif yang diperlihatkan oleh individu atau kelompok terhadap individu lain atau kelompok lain. Prasangka sosial dapat berkembang dikarenakan beberapa faktor salah satunya faktor kognisi sosial yaitu dari bagaimana cara individu berfikir mengenai individu lain. Meskipun terjadi prasangka sosial antar pembudidaya tapi tidak mengurangi tenggang rasa, kerja sama dan rasa solidaritas antar pembudidaya satu dan yang lain. 
c. Meningkatkan interaksi antara pembudidaya dengan pemerintah

Harga ikan yang fluktuatif memberikan dampak cukup besar bagi pembudidaya ikan kerapu. Adanya kebijakan pemerintah tentang penghentian sementara penerbitan izin kapal pengangkut ikan hidup, secara tidak langsung berdampak pada pasar ekspor ikan kerapu di Kabupaten Situbondo. Dampak yang timbul dari kebijakan tersebut adalah banyak pembudidaya yang mogok melakukan usaha budidaya ikan kerapu karena harga ikan yang sebelumnya bekisar Rp 150.000 hingga Rp 160.000 menjadi Rp 75.000 hingga Rp 80.000. Bentuk interaksi pembudidaya dengan anggota PPIK lain menanggapi kebijakan yang ada dengan melakukan protes tetapi tidak memicu konflik dengan menyampaikan ususlan serta keluh-kesah yang dialami oleh pembudidaya. Sejalan dengan penelitian Charles H. Coopley yang dikutip oleh Taneko (1984), apabila seseorang menyadari bahwa mereka mempunyai kepentingan-kepentingan yang sama, dan pada saat yang bersamaan mempunyai cukup pengetahuan, bentuk pengendalian terhadap diri sendiri yang akan dilakukan untuk memenuhi kepentingan-kepentingan tersebut adalah melalui kerjasama. Protes yang dilakukan pembudidaya cukup berdampak pada harga ikan yang sebelumnya dalam range harga $\mathrm{Rp} 75.000$ - Rp 80.000 menjadi Rp 80.000- Rp 100.000 meskipun tidak senormal tahun-tahun sebelumnya.

Langkah lain yang dilakukan oleh pembudidaya selain mengembangkan pasar domestik khususnya Pulau Jawa juga dengan menambah komoditas ikan lain dengan masa panen yang lebih singkat. Komoditas ikan yang dipilih adalah ikan kakap yang merupakan rekomendasi dari Dinas Perikanan Kabupaten Situbondo sambil menunggu harga ikan kerapu kembali normal agar tidak semakin banyak SDM yang kehilangan mata pencaharian. Menurut Sarwono \& Meinarno, (2015), bentuk interaksi sosial antara pembudidaya dengan pemerintah adalah mensejahterakan pembudidaya yang dilakukan dengan pertemuan dan negosiasi tentang harga dan jenis ikan yang dibudidaya untuk mendapatkan solusi terbaik, meskipun bagi pembudidaya hal tersebut masih dirasa kurang dan tetap menyebabkan kerugian.

d. Meningkatnya aksesibilitas

Selain interaksi dan prasangka sosial antar pembudidaya, dampak sosial lainnya adalah berkembangnya aksesbilitas yaitu berupa infrastruktur yang ikut menunjang pembangunan dalam usaha budidaya ikan kerapu keramba jaring apung, seperti dermaga dan taman kecil dan jalan setapak atau pedestrian yang berguna sebagai salah satu cara untuk menarik dan mempermudah akses konsumen kepada pembudidaya.

Dalam praktik pembangunan di beberapa daerah dengan ketersediaan infrastruktur yang lebih memadai akan mempengaruhi aktivitas perekonomiannya pula. Menurut Farida (2013), ketersediaan infrastruktur yang lebih memadai, aktivitas perekonomian di kawasan perkotaan semakin berkembang, sedangkan kawasan pedesaan yang minim akan infrastruktur mensjadi sedikit tertinggal dari ekonomi perkotaan. Dalam kawasan pedesaan, aksesibilitas memiliki peranan yang penting karena keberadaannya dapat merangsang tumbuhnya pasar dan produktivitas pertanian juga akan meningkat, seperti yang dilakukan oleh pemerintah di Kabupaten Situbondo yang melakukan pembangunan untuk menunjang kegiatan perekonomian khususnya untuk pembudidaya ikan kerapu menggunakan keramba jaring apung. 


\section{Dampak Ekonomi}

Selain dampak sosial, pembudidaya juga mengalami perubahan setelah adanya pengembangan usaha budidaya ikan kerapu keramba jaring apung. Perubahan tidak hanya meliputi perubahan sosial tapi perubahan ekonomi justru lebih dirasakan oleh pembudidaya karena dengan adanya usaha ikan kerapu sudah dipastikan membuka lapangan kerja dan lapangan usaha, baik langsung maupun tidak langsung karena dapat memperbaiki keadaan perekonomian kepada pembudidaya yang baru melakukan usaha budidaya maupun yang sudah lama berkecimpung di dalamnya. Dampak langsung yang diterima pembudidaya adalah jumlah pendapatan yang bertambah karena permintaan kerapu ekspor meningkat dengan harga yang lebih tinggi dari harga domestik. Perekonomian jadi meningkat sehingga dapat memenuhi kebutuhan primer, sekunder hingga tersier. Fluktuatisi harga ikan sempat menyebabkan menurunnya produksi tapi pembudidaya masih merasa cukup dalam memenuhi kebutuhan sehari-hari dan tetap optimis harga ikan akan kembali normal. Penjelasan komperhensif mengenai hal tersebut diringkas dalam teori ekspektasi.

Menurut Robbins (2002), kekuatan dari kecenderungan untuk bertindak dengan cara tertentu tergantung pada kekuatan dari suatu harapan bahwa tindakan tersebut akan diikuti dengan hasil tertentu serta pada daya tarik hasil tersebut bagi individu yang bersangkutan. Pembudidaya tetap memiliki keinginan untuk menambah dan mengembangkan usaha dan terus belajar agar produksi ikan meningkat setiap panennya. Berbagai cara dilakukan agar usaha budidaya ikan kerapu keramba jaring apung mendapat keuntungan dan kembali stabil, karena harga ikan kerapu setiap jenisnya berbeda. Seperti saat pada bulan-bulan tertentu ikan kerapu cantang memiliki harga yang lebih tinggi dari ikan kerapu cantik atau komoditas ikan kerapu lainnya begitupun sebaliknya. Hal lain yang menyebabkan tetap dilakukan usaha budidaya karena mempunyai usaha sampingan yang berhubungan dengan perikanan seperti usaha pembenihan ikan dan penggelondongan.

\section{KESIMPULAN}

Keberadaan usaha budidaya ikan kerapu dengan menggunakan keramba jarring apung memberikan dampak dari segi sosial dan ekonomi. Dampak sosial yaitu terbentuknya Perkumpulan Pembudidaya Ikan Keramba Jaring Apung (PPIK) yang menciptakan jaringan sosial melalui interaksi yang terjalin antar pembudidaya. Munculnya prasangka sosial sesama pembudidaya karena persaingan usaha serta kebijakan dari pemerintah. Berkembangnya aksesibilitas berupa pembangunan fasilitas yang ikut menunjang sarana prasana serta pendapatan pembudidaya. Sedangkan dampak ekonomi yang terbentuk yaitu meningkatnya pendapatan dan perekonomian keluarga. Pembudidaya ikan kerapu di mempunyai penghasilan yang memadai sehingga dapat memenuhi kebutuhan sehari-hari maupun fasilitas kehidupan seperti tabungan, kendaraan bermotor dan peralatan elektronik. 


\section{DAFTAR PUSTAKA}

Adhyaksa, D. (2008). Pemuda dan Kelautan. Jakarta: Pustaka Cidesindo. Ahmadi, A. dan S. W. (2004). Psikologi Belajar. Jakarta: Rineka Cipta. Arifin, B. (2015). Psikologi Sosial (B. Saebani, Ed.). Bandung: CV Pustaka Setia.

Bian, R. (2010). Kajian Sosial Ekonomi Masyarakat Pembudidaya Ikan Kerapu Dalam Keramba Jaring Apung Di Desa Posi-Posi Kabupaten Halmahera Selatan. Universitas Terbuka Jakarta.

Farida, U. (2013). Pengaruh Aksesibilitas terhadap Karakteristik Sosial Ekonomi Masyarakat Pedesaan Kecamatan Bumijawa Kabupaten Tegal. Jurnal Wilayah Dan Lingkungan, 1(1), 49-66. https://doi.org/10.14710/jwl.1.1.49-66

Gunarto, A. (2003). Pengembangan Sea Farming Budidaya Keramba Jaring Apung (Kja) Kerapu (Ephinephelus Sp.) di Indonesia. Jurnal Matematika Sains Dan Teknologi, 4(1), 35-44.

Ismi, S. (2013). Lama Waktu dan Kepadatan Telur dalam Upaya Perbaikan Teknologi Transportasi Tertutup pada Telur Kerapu. Jurnal Ilmu Dan Teknologi Kelautan Tropis, 5(1), 54-59.

Langkosono. (2007). Budidaya Ikan Kerapu (Serranidae) dan Kualitas Perairan. Neptunus, 14(1), 61-67.

Loekman, N. A., Satyantini, W. H., \& Mukti, A. T. (2018). Penambahan Asam Amino Taurin pada Pakan Buatan terhadap Peningkatan Pertumbuhan dan Sintasan Benih Ikan Kerapu Cantik (Epinephelus fuscoguttatus $\times$ Epinephelus microdon) [Addition of Amino Taurine Acid to Artificial Feed on Increased Growth and Surv. Jurnal Imiah Perikanan Dan Kelautan, 1O(2), 112-118. https://doi.org/10.20473/jipk.v10i2.10504

Moleong, L. J. (2010). Metode Penelitian Kualitatif: Edisi Revisi. Bandung: PT. Remaja Rosdakarya.

Paruntu, C. P. (2019). Budidaya Ikan Kerapu (Epinephelus tauvina Forsskal, 1775) dan Ikan Beronang (Siganus canaliculatus Park, 1797) dalam Karamba Jaring Apung dengan Sistim Polikultur. E-Journal BUDIDAYA PERAIRAN, 3(1), 1-10. https://doi.org/10.35800/bdp.3.1.2015.6924

Rahmaningsih, S., \& Ari, A. I. (2013). Pakan dan Pertumbuhan Ikan Kerapu Cantang (Epinephelus fuscoguttatus-lanceolatus). Jurnal Ekologia, 13(2), 25-30.

Renanti, H. F. (2015). Analisis Strategi Pengembangan Usaha Hatchery Skala Rumah Tangga (HSTR) Kerapu di Kecamatan Bungatan Kabupaten Situbondo. Universitas Jember.

Robbins, P. S. (2002). Prinsip Prinsip Perilaku Organisasi. Jakarta: Erlangga.

Sarwono, S., \& Meinarno, E. A. (2015). Psikologi Sosial. Jakarta: Salemba Humanika.

Suhana. (2017). Ekonomi Perikanan Budidaya Kerapu.

Taneko, S. B. (1984). Struktur dan Proses Sosial: Suatu Pengantar Sosiologi Pembangunan. Jakarta: Rajawali.

Triana, H. (2010). Analisis Fragmen DNA Ikan Kerapu Macan ( Epinephelus fuscoguttatus ) yang Tahan dan Rentan terhadap Bakteri Vibrio alginolyticus. Jurnal Ilmu Dasar, $11(1), 8-16$. 